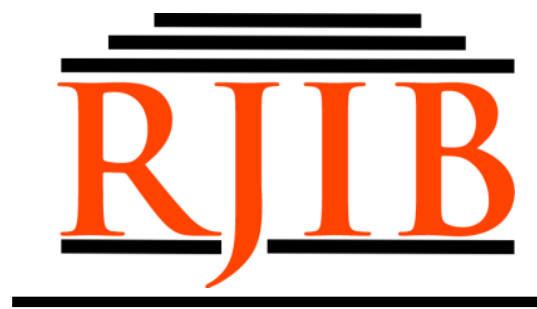

RETORIKA: Jurnal Ilmu Bahasa

Vol. 7, No. 1 April 2021, Page 75-84

P-ISSN: 2406-9019

E-ISSN: 2443-0668

Available Online at https://ejournal.warmadewa.ac.id/index.php/jret

\title{
The Effectiveness of Flipped Learning During the Pandemic to Improve the Writing Competence of STMIK STIKOM Indonesia Students
}

\author{
Kadek Yogi Susana \& A.A. Gede Raka Wahyu Brahma \\ STMIK STIKOM Indonesia \\ yogi.susana@stiki-indonesia.ac.id and gungbrahma@yahoo.co.id
}

\begin{tabular}{|l|}
\hline How to cite (in APA style): \\
Sublished: 30/04/2021 \\
$\begin{array}{l}\text { Suna, K. Y. \& Brahma, A. (2021). The Effectiveness of Flipped Learning During the Pandemic to Improve the Writing } \\
\text { Competence of STMIK STIKOM Indonesia Students. RETORIKA: Jurnal Ilmu Bahasa, 7(1), 75-84. Doi: } \\
\text { https://doi.org/10.22225/jr.7.1.2883.75-84 }\end{array}$
\end{tabular}

Abstract- Characteristically flipped learning enables students to utilize their time in class schedule to have discussion and elaborate their analysis especially in writing. The students can obtain learning experience which will shape their English. The research was aimed to determine the effectiveness and impact of flipped learning on developing writing competence of students during the COVID-19 pandemic. There are 32 fourth semester students majoring in Informatics Engineering STMIK STIKOM Indonesia who are the objects of this research. This research was conducted in the form of CAR (Class Action Research) which included the stages of planning, implementing action, observation and reflection which were carried out in two cycles. This study adopts the threestage model proposed by Estes et al. (2015) for flipped learning: pre-class, in-class and post-class stages. Quantitative data were acquired from the eventual outcomes of convincing articles arranged by the students when the usage of flipped learning. Quantitative data, especially three kinds of data; (pre-test and post-test 1), (pre-test and post-test 2) and (post-test1 and post-test2) were examined utilizing SPSS 21 statistics. The correlation coefficient (r) for the principal informational index was 0.769 and the subsequent informational index was 0.907 . The scope of all the correlation coefficients infers that there is an intensive connection among when the use of flipped learning. In view of the aftereffects of the examination utilizing SPSS statistics 21 with a certainty level of $95 \%$, it is realized that $\mathrm{H} 1$ is acknowledged and $\mathrm{H} 0$ is dismissed, implying that there is a huge impact on the use of flipped learning in improving students' writing ability.

Keywords: Flipped learning; writing competence; English for Specific Purposes

\section{INTRODUCTION}

Teaching writing in the English for Specific Purposes (ESP) class is important for students, because the writing process not only improves students' linguistic aspects including vocabulary and grammar through exposure to related literature but also sharpens students' analytical thinking about certain problems based on the students' field of science. Writing requires students to have a series of phases that provide space for them to experience deep learning before completing assignments. However, because English is not a core subject, there are time limits due to limited sessions at each class meeting. This inevitable situation usually results in students struggling and learning at home about essays on their own without any feedback from teachers or classmates. One solution to this problem in particular can be found in the application of flipped learning (hereinafter abbreviated as FL). Numerous researches have detailed measurably significant outcomes within 
the implementation of FL compared to traditional classroom learning methods (Davies, Dean, \& Ball, 2013; Ferreri \& O' Connor, 2013; Han, 2015; Tune, Sturek, \& Basile, 2013)

Compared to traditional teaching methods, FL provides space for students to discuss learning barriers during online discussions and increases the involvement of students who are still embarrassed to speak in class. Despite the fact that the lecture format with a traditional approach allows lecturers to actively convey material and convey information to students in a limited period of time, a lecturer-centered learning approach will limit the dialogue between lecturers and students. As a result, students passively receive material exposure based on instructions given in class and reflect the lecturers' thoughts when completing an assignment. In other words, the student learning process cannot develop due to monotonous learning styles and the inability to practice the skills that have been learned during the lecture process (Wallace, Walker, Braseby, \& Sweet, 2014). On the other side, FL gives learning chances for students to experience a learning process that suits their needs by reversing the strategy of delivering lecture material. Outside the classroom setting, students are preoccupied with lower degrees of analytical work (picking up information and acknowledging) and whereas within the classroom, they lock in in higher stages of analytical movement (application, analysis, synthesis, and or assessment) since they are bolstered by their lecturers and classmates.

In the scope of teaching writing, the instructor still gives assignments to students, but in the context of FL, students are required to read material or watch videos related to supporting theories of writing competence or watch lecture videos that have previously been recorded and posted online by the lecturer. Thus, limited sessions in class can be used to discuss difficulties faced by students, equate perceptions and carry out activities that are centered on collaborative activities in groups. Conservative lectures also waste precious resources and unable to take advantage of the expertise, knowledge and skills of the teacher by encouraging him to transmit the similar information to multiple audiences (Sankoff, 2014). Students are also hesitant to talk and ask for guidance in such a conventional setting, whereas lecturers are required to have information (Harris, Harris, Reed, \& Zelihic, 2016).
In this research, Google Classroom was connected to be utilized as a digital learning stage for students regarding to a few contemplations. To begin with, this application has been utilized broadly by instructors around the world since it is free and simple to utilize. Then, several former researches have detailed that students have positive states of mind over the utilize of Google Classroom, counting analysis conducted by (Alkathiri, 2015; Arroyo, 2011; Balasubramanian, Jaykumar, \& Fukey, 2014). To enable students, know the course purposes and apply Google Classroom, students have been prepared when the class action starts. Here classrooms which runs virtually can be arranged for students to do group assignments together. Besides observing video clips or PowerPoint slides, lecturers and students are able to share substance, talk about points, get their lecturer's input and obtain the grades effectively. Google Classroom generates advancement, inventiveness, dynamic cooperation and teamwork (Wichadee, 2017).

Taking into account the fact that writing involves a series of stages that cannot be covered in formal time-limited meetings, Google Classroom is implemented to provide students with extra preparation and discussion outside of class hours. Therefore, the use of FL through Google Classroom in this study is expected to provide space to help students study material more comprehensively and to focus on learning language content that cannot be fully discussed during face-to-face meetings.

An illustration of a comparison of traditional classrooms and FL can be presented in Figure 1 below:

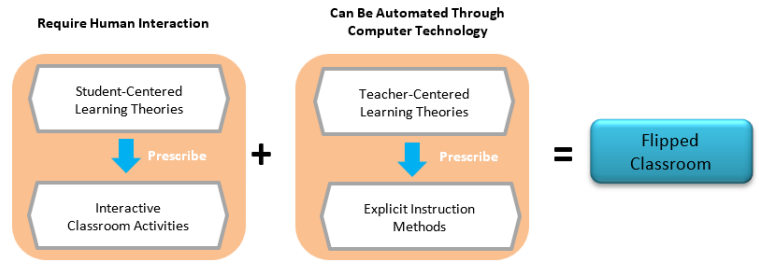

Figure 1: Flipped Learning Activities (Bishop \& Verleger, 2013)

In the FL class, the highest level (creating) is practiced following the lower level. In the application of the FL model, the lower cognitive domains, namely remembering, and understanding are presented outside the classroom through videos, reading and other materials. Hence, applying, analyzing, assessing, and making as a better level of cognitive work is 
able to be implemented within the classroom. Bergmann \& Sams (2012), in their blog states that FL class focuses on time spent with the guidance of an instructor in the upper layer of the triangle. The following Figure 2 provides information about the level of student educational process within the FL concurring to Bloom's updated scientific categorization.

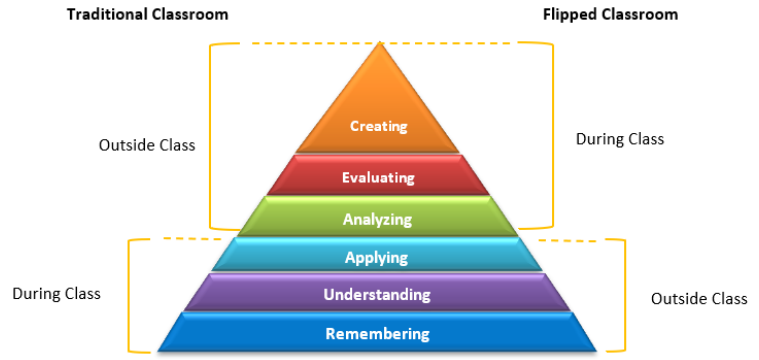

Figure 2: Revised Bloom's Taxonomy in FL (Güvenç, 2018)

Many types of research have reported the relationship between classroom application and effectiveness with the FL pedagogical approach (Güvenç, 2018; Soliman, 2016; Szparagowski, 2014). Moreover, (Mclaughlin et al., 2014) emphasized that the FL method incorporates student-centered educational process that empower the enhancement of maximum critical aptitudes such as explanatory aptitudes, issue framing abilities, basic analyzing abilities, and inventive mind. Subsequently, the application of the FL educating method within the setting of English for Specific Purposes (ESP) may be a reaction to the nonstop advancement step adjusted to English learning (Emaliana, 2017). Other analysts counting (Sun \& Wu, 2016) and (Güvenç, 2018) also analyze FL by utilizing the same methods as this research, specifically in terms of course activity.

The research appears that FL not only assists the students get the substance beyond the classroom but also distributes lesson time for two-ways exercises, by turning around traditional educating models and captivate the students in hands-on exercise through teamwork. So this method can prevent misunderstandings between lecturers and students through class discussions. Concepts and materials that have been studied during the pre-class duration are reviewed and discussed in a deeper context. The FL method is a model for other institutions and or schools to provide learners with alternative teaching techniques that can help them "think outside the box". Based on all the research above, the application of reverse learning using Google Classroom in this ponder points to check the adequacy of FL in developing students writing skill in pandemic situation.

This pandemic has an impact on education, including higher education. Preventive action against the spread of COVID-19 has affected the education system in the world and even academic institutions must be temporarily closed. The presence of this virus hinders learning activities that are usually carried out in direct meetings. The learning system is carried out remotely by utilizing information technology. This encourages educational institutions to use more information technology (internet) in distance learning activities. Online learning has become widespread today and results in students' online learning experiences and their focus on time management. There are several recent studies that discuss the topic of applying the flipped learning method during the COVID-19 pandemic, including (Guraya, 2020; Khan \& Abdou, 2020).

Previous studies on FL during the pandemic emphasized that this approach can help students build active learning habits supported by lecturers, but also lead to empowerment of active and independent learning as an important part of face-to-face learning thereby increasing students' sense of responsibility. to study independently in a supportive environment. Lecturer support and guidance can focus on certain obstacles and encourage student involvement in certain discussions through student involvement in these activities. The FL method is recommended to be applied during a pandemic because it not only improves understanding of the material but also encourages active and independent learning for students (Susana \& Brahma, 2020). New topics can be introduced and meetings can take place via online video either via Skype, Zoom, or Google Meet. In addition to similar methods, this research focuses on a different topic, namely teaching persuasive essay writing for IT students by using Google Classroom as an online platform for transferring learning materials, slides, quizzes, discussion materials, and assignments and Google Meet for face-to-face online discussions. interactive. It is hoped that the application of this method can provide sufficient time for students and guide them to the next stage. Once online face-to-face classes have started, the material can be checked and problems discussed. Thus, this will improve student 
learning, especially when the current situation requires us to fully adapt to online learning. This research is also expected to provide a deeper and more interactive learning experience for students with limited time for face-to-face lectures.

\section{METHODS}

This quantitative research utilized a system of classroom activity. A plan inside the system of this classroom activity involves these steps: Planning (understanding the problem at hand and taking action in the form of an investigation), Action (a systematic and vigorous effort to intervene with the problem), Observation (collecting comprehensive data related to action). Last but not least it is very important to look back at the research once it is done. Based on the core concept of CAR, this research follows a series of iterative steps. Complete the first cycle, then the cycle starts all over again, with the revision put into new action. This process enables lecturers who wish to investigate classroom activities on their own to take constructive steps to solve problems directly, systematically reflecting on the results. Thus, the aim of classroom action research is to achieve local understanding and develop viable solutions to problems.

This project aims to evaluate the writing achievement of students through FL. This study includes the conveyance of substance within the learning handle for one semester which is separated into two sorts of learning, specifically the conventional face-to-face lesson style and two FL cycles during classroom activity. Each cycle is carried out in 4 meetings. Thus, the two cycles in this study lasted 8 weeks. Objects in this research were 32 fourth semester students in the undergraduate level of Informatics Engineering at STMIK STIKOM Indonesia. This activity is carried out in English class III as a compulsory English class that students take in their studies.

The FL approach gives instructing and learning exercises where students observe directions videos and studied learning substance beyond the classroom through distance learning and have direct classroom exercises in formal class. Online lessons enable students to work together during academic time that ought to be done on learning schedule. Therefore, making a learning model in FL is very meaningful because it is closely related to the learning environment of students (Mehring, 2016). This study adopts the three-phase type suggested by (D, Ingram, \& Liu,
2015) to reverse the learning process, namely the pre-class stage (modeling, pre-assessment), in the classroom (explaining blue-print, overcoming problems) and the post-class stage (assessment, application, transfer). In this particular study, several adjustments were made to suit the objectives and classroom situation as shown in Figure 3 below.

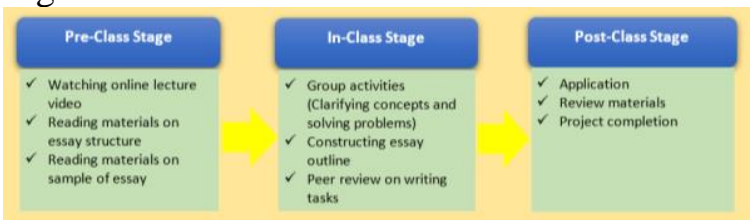

Figure 3: Flipped Learning Class Design (D et al., 2015)

There are 16 meetings in the class. Students and lecturers meet in the classroom once a week for two learning sessions lasting 100 minutes. As such, students benefit from extra hours during the pre-class and post-class stages where online forums are open for week-long discussion. The descriptions of each stage in FL used in this study are as follows.

\section{Pre-class Stage: Self-Study on Google Classroom}

The pre-class phase points to assist students analyze information by means of learning innovation. Creating information or studying updated substance is conducted at home for the course. Students are invited to observe educational videos about essay writing and answer questions or discuss the task of analyzing sample essays based on content in Google Classroom which is used as an online platform for learning. In this course, students learn how to formulate opinions and persuasive essays on "Computer or Information Technology (IT)".

\section{In-Class Stage: Group Activities and Peer Review}

Course time went through more on exercises. Group exercises rise peer interaction, center more on cognitive and upper collective learning involving lower collective process, issue framing (worksheets on analyzing essay structure) and peer review of writing assignments. In the second cycle, students worked in groups to compile an essay outline and posted it on Google Classroom to get feedback from lecturers and other friends. After the outline is reviewed, each student develops the outline into an individual essay. In this way, dynamic learning encounters will happen within the class. The benefit of this phase is to energize the 
advancement of basic analytical and solutionoriented abilities, while progressing interpersonal abilities.

\section{Post Class Stage: Implementation, Review and Project Completion}

The post-class stage aims to provide opportunities for students to apply what they have learned including completing exercises and writing assignments. The essay that was completed by students in the second cycle was taken as a student's final project. In addition, they are asked to evaluate their learning performance on assignments, assignments, and activities.

The post-class phase aims to supply chances for students to implement what they have studied involving accomplishing task and writing assignments. The writing that was accomplished by students within the second cycle was formed as a student's final test. Then, they are invited to assess their learning process on tasks, assignments, and exercises.

\section{Types of Data and Data Analysis}

The information in this research contains quantitative data gained from the pre-test and post-test writings composed by students before and after the usage of the activity within the frame of the implementation of the FL learning strategy.

The pre-test scores were taken from the writing submitted by students when taught using a traditional approach. Meanwhile, the post-test scores were taken from two essays completed by students in the first and second cycle of the FL process, respectively. Thus, quantitative data consists of three data sets, namely (pre-test and post-test1), (pre-test and post-test2) and (posttest 1 and post-test2). Both cycles are carried out through a framework as described in Figure 1 with an emphasis on new actions in the form of collaborative work in building an essay framework in the second cycle. This action is carried out based on reflection after the first cycle is complete. Based on these reflections, students are faced with challenges in compiling an outline with a good structure. As such, it interfered with the process of developing ideas into complete essays because they found it difficult to provide supporting details with a good flow of ideas. In the second cycle, students work together to create an outline, review an outline and are encouraged to work on the research process collaboratively.

The outcome of the pre-test and post-test evaluations were studied utilizing the SPSS 21 statistic program to know the impact of FL on developing students' learning accomplishment. Paired sample statistics are utilized to decide the average value on the pre-test and post-test to view the distinction. In the mean time, paired sample correlation is utilized to get the correlation coefficient (R). This examination is utilized to decide the quality of the relationship before and after FL is actualized within the education program. Besides, Paired-sample t-test was utilized to study whether there was a noteworthy distinction in students' English writing accomplishment before and after students were instructed utilizing FL through two cycles which were in 8 meetings.

\section{RESULTS AND DISCUSSION}

The FL teaching method involves an innovative process in the delivery of learning material, the learning process involves the process of transferring material that is usually delivered in the classroom through traditional lecture methods out of the classroom through materials that can be accessed online. FL also involves the process of reversing the context of the place, time and manner of delivery of material. Therefore, assignments that are usually given to students to be completed outside the classroom are carried out in the classroom. The learning material of the taught writing competencies has been given outside the classroom. This contrasts from the conventional type which depends on class instructors as the primary shape of education. Pre-class exercises (other than delivering assignments in classroom) offer assistance to instructors to give more time within the handle of relationship between students therefore they can be effectively participated (Roehl, Reddy, \& Shannon, 2013; White et al., 2017). This activity occurs especially in the FL learning process which fosters student independence and then they can get FL feedback during Live Session or Online Discussion as shown in Figure 4.

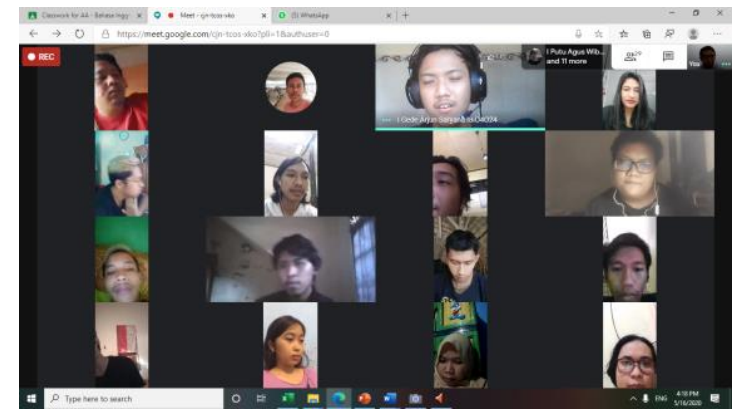


Figure 4. Screenshot of Online Discussion through Google Meet

FL in this research was conducted after students involved a learning phase with a traditional kind of process. The pre-test and posttest were implemented to check the impact of FL on students' writing skill. This task is within the frame of assignment that students are invited to create a influential sort of paper based on the given theme. A pre-test was decided to get them score data before the intercession within the form of FL execution was carried out within the studying program. At that point, a post-test was here to decide the impact of FL on students' writing skill within the shape of values analyzed quantitatively.

Prior to the implementation of FL, students received material exposure about persuasive essays and then students were asked to complete writing assignments and produce individual essays with the topic "Computer or Information Technology (IT)". After they completed and collected the pre-test essays, the FL cycle began to be implemented through an online learning management system, namely Google Classroom. Students are divided into groups of five so they can work collaboratively. Students work together as a team, especially at the stage of drafting an outline and the peerreview process, then transferring their roles to be responsible for the process of working on individual essay projects with the topic "Computer or IT". This method is similar to the finding of Han (2015) which reverses the intensive learning process of ESL (English as a Second Language) courses by implementing a digital platform for input that is focused on meaning and language and provides cooperative activities for in-class meeting sessions. The findings in his study reveal a significant development of student independence. Before moving further into elaborating the findings in this research, several screenshots of interactive learning activities in Google Classroom using mobile devices are shown in Figure 5 below.
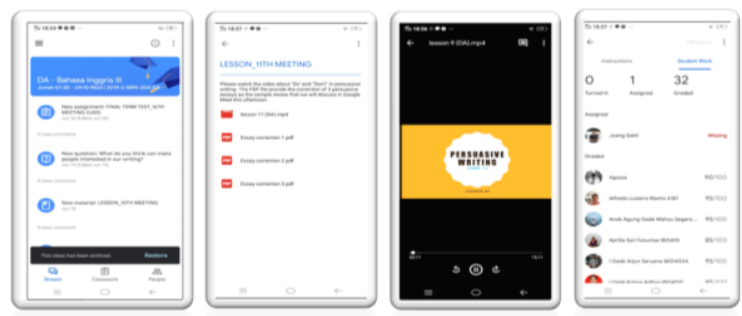

Figure 5: Screenshot of Google Classroom Implementation

This image contains online material discussed in Google Classroom for students to explore during pre-class activities. The material given is a video on how to write a persuasive essay. This is an example of the Google Classroom interface that displays material in the form of a learning video. Another type of material is an example essay that should be read at home for further analysis during class activities. Meanwhile, the third and fourth images show online interactions in post-class activities where students and lecturers discuss reviews or responses to student outlines.

Table 1 here appears the outcome of the examination of the pre-test and post-test scores within $1^{\text {st }}$ cycle, the pre-test vale with the $2^{\text {nd }}$ cycle post-test, and the comparison between the outcome of the post-test within the $1^{\text {st }}$ cycle and $2^{\text {nd }}$ cycle. The outcome of information preparing utilizing paired samples statistics appears that the normal pre-test score of students is 74.22, whereas the mean writing value of students after the usage of flipped learning within the to $1^{\text {st }}$ cycle is 83.13. In the mean time, the comparison of the students 'pre-test mean value was 74.22, while the students' mean value after the usage of flipped learning within the $2^{\text {nd }}$ cycle was 86.88 . The comparison between the mean post-test values within the to $1^{\text {st }}$ and $2^{\text {nd }}$ cycles moreover appeared an increment, from 83.33 to 86.88 .

Table 1. Paired Samples Statistics

\begin{tabular}{|ll|c|r|r|r|}
\hline & \multicolumn{1}{|c|}{ Mean } & \multicolumn{1}{c|}{$\mathrm{N}$} & $\begin{array}{c}\text { Std. } \\
\text { Deviation }\end{array}$ & $\begin{array}{c}\text { Std. Error } \\
\text { Mean }\end{array}$ \\
\hline Pair 1 & Pre_Test & 74.22 & 32 & 7.196 & 1.272 \\
& Post_Test_Siklus1 & 83.13 & 32 & 7.594 & 1.342 \\
Pair 2 & Post_Test_Siklus1 & 83.13 & 32 & 7.594 & 1.342 \\
& Post_Test_Siklus2 & 86.88 & 32 & 7.906 & 1.398 \\
\hline
\end{tabular}

Following are the results of data processing obtained for the results of the average score of 32 students.

Case 1: Before participating in flipped learning, the student's average score was 74.22. Meanwhile, after participating in flipped learning the average value was 83.13.

Case 2: Before participating in flipped learning, the average score of the students was 83.13. Meanwhile, after participating in flipped learning the average value was 86.88

Standard Deviation could be a degree of the distribution that appears the standard deviation of the information from its mean score. 
If the standard deviation is small, it indicates the sample values from the population clustered or clustered around the mean value. Because the value is almost the same as the average, we can conclude that every member of the sample or population has something in common.

A large standard deviation indicates a large difference between members of the population; therefore a high standard deviation is considered unfavorable.

\section{Case I:}

In this case, it shows that the standard deviation value in the Post-test Cycle 1 data (7.594) is greater than the Pre Test (7.196), which shows that the pre-test I data is better than the post test.

\section{Case II:}

In this case, it shows that the standard deviation value in the post test cycle 2 data $(7,906)$ is smaller than the post test cycle 2 $(7,594)$, which shows the post test data cycle 1 is better than the post test cycle 1 .

Table 2. Paired Samples Correlations

\begin{tabular}{|ll|r|r|r|}
\hline & \multicolumn{1}{|c|}{ N } & Correlation & \multicolumn{1}{c|}{ Sig. } \\
\hline Pair 1 & $\begin{array}{l}\text { Pre_Test \& } \\
\text { Post_Test_Siklus1 }\end{array}$ & 32 & .769 & .000 \\
Pair 2 & $\begin{array}{l}\text { Post_Test_Siklus1 } \\
\& \\
\text { Post_Test_Siklus2 }\end{array}$ & 32 & .907 & .000 \\
\hline
\end{tabular}

This analysis is used to determine the strength and weakness of the relationship between before participating in flipped learning and after applying flipped learning.

Table 3. Interpretation of the Correlation Coefficient

\begin{tabular}{|c|c|}
\hline \begin{tabular}{l}
\multicolumn{2}{c}{ The } \\
Level of \\
Correlation \\
coefficient, $\quad r$ \\
(positive/ \\
negative)
\end{tabular} & Interpretation \\
\hline $0,001-$ & $\begin{array}{l}\text { Very weak / Low } \\
\text { correlation }\end{array}$ \\
\hline $0,201-$ & Weak / Low Correlation \\
\hline 0,700 & $\begin{array}{l}\text { Fairly strong / High } \\
\text { correlation }\end{array}$ \\
\hline 0,900 & $\begin{array}{l}\text { Strong / High } \\
\text { correlation }\end{array}$ \\
\hline 1,000 & $\begin{array}{l}\text { Very strong / High } \\
\text { correlation }\end{array}$ \\
\hline
\end{tabular}

\section{Case I:}

Regarding to the outcome of the study, the correlation coefficient $(\mathrm{R})=0.769$ was obtained. Furthermore, based on the height - low of the relationship, the correlation coefficient $(\mathrm{R})$ of $=$ 0.769 lies between 0.701-0.900 that shows the relation is strong. The probability value also shows that it is still below 0.05 (data shows that the output significance value is 0.00 ). This shows that there is a very intensive correlation before participating in flipped learning and after participating in flipped learning.

\section{Case II:}

Regarding to the outcome of the study, the correlation coefficient $(R)=0.907$ was obtained. Furthermore, based on the height - low of the relationship, the correlation coefficient $(\mathrm{R})$ of $=$ 0.907 lies between 0.901-1,000, which means that the correlation is very strong. The probability value also shows that it is still below 0.05 (data shows that the output significance value is 0.00 ). This means that there is a strong or high positive relationship between before participating in flipped learning and after participating in flipped learning

Table 4. Paired Samples Test

\begin{tabular}{|c|c|c|c|c|c|c|c|c|}
\hline & \multicolumn{5}{|c|}{ Paired Difierences } & \multirow{2}{*}{$t$} & \multirow{2}{*}{$d f$} & \multirow{2}{*}{$\begin{array}{l}\text { Sig, (2-2 } \\
\text { talied) }\end{array}$} \\
\hline & Mean & $\begin{array}{c}\text { Std. } \\
\text { Deviation }\end{array}$ & $\begin{array}{l}\text { Sodt Error } \\
\text { Mean }\end{array}$ & \multicolumn{2}{|c|}{$\begin{array}{l}\text { 95X Confidence Interval of } \\
\text { the Difference }\end{array}$} & & & \\
\hline 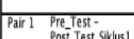 & $\frac{\text { Mean }}{-8.906}$ & $\begin{aligned} \text { Devadion } \\
5.038\end{aligned}$ & Mean & $\begin{array}{l}\text { Loner } \\
-10.723\end{array}$ & $\begin{array}{l}\text { Cpper } \\
-7.090\end{array}$ & -10.001 & $\frac{d f}{31}$ & $\frac{\text { tallead) }}{.000}$ \\
\hline Pair2 PostTest_Skikis1 & -3.750 & 3.360 & .594 & -4.961 & -2.539 & -6.313 & 31 & .000 \\
\hline
\end{tabular}

This task is utilized to decide whether or not there is an average difference between two paired (related) sample groups. The point here is that a sample is subjected to two different treatments, so that the effect between before participating in flipped learning and after following flipped learning is known.

The statistical test steps are as follows:

\section{Formulate a hypothesis}

$\mathbf{H}_{0}$ : shows there is no remarkable impact between before taking flipped learning and after following flipped learning.

$\mathbf{H}_{1}$ : shows there is no remarkable impact between before participating in flipped learning and after following flipped learning.

\section{Decision-making}

Basic decision making:

We can compare $t_{\text {count }}$ and $t_{\text {table }}$

If $\mathrm{t}_{\text {count }}<\mathrm{t}_{\text {table }}$ or $-\mathrm{t}_{\text {count }}<-\mathrm{t}_{\text {tabel }}$ then $\mathrm{H}_{0}$ is accepted rejected

If $t_{\text {count }}>t_{\text {table }}$ or $-t_{\text {hitung }}>-t_{\text {table }}$ then $\mathrm{H}_{0}$ is

The degree of significance is decided utilizing a degree of confidence of $95 \%$ or an error rate of $5 \%(\alpha=0.05)$. 
Where the confidence level is $95 \%$ and the value is sig. $(\alpha)=0.05$, then the value of $\mathrm{df}$ (degree of freedom $)$ or degrees of freedom $=(n-$ k) $=32-1=31$

The test is carried out in two sides because it will be known whether the pre-test average is the same as the post-test or not. So, it can be bigger or smaller, therefore a two-sided test is used.

With a two-sided test, each side has a value of $\alpha / 2=0.05 / 2=0.025$ to determine the $t_{\text {table }}$ value. The $t_{\text {table }}$ value $(0.025 .31)$ is \pm 2.03951

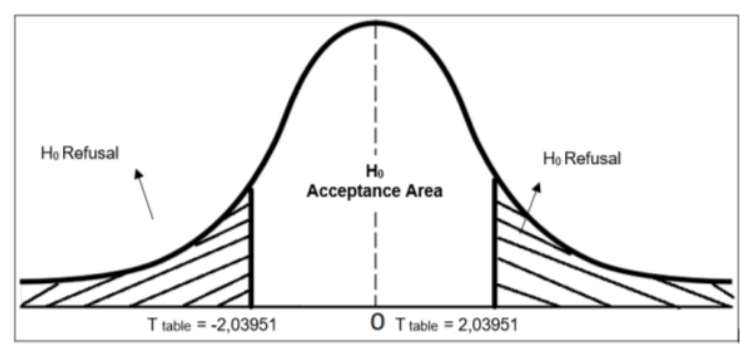

Figure 6. Test area

\section{Case I:}

Regarding to the outcome of the study using the SPSS statistic 21 program at the $95 \%$ confidence level showed that $t_{\text {count }}$ was $-10,001$, which was greater than $t_{\text {table, }}$ which was -2.03951, so $\mathrm{H}_{0}$ was refused, shows there was a remarkable impact between before participating in flipped learning and after participating in flipped learning.

\section{Case II:}

Regarding to the outcome of the study using the SPSS statistic 21 program at the $95 \%$ confidence level showed that $t_{\text {count }}$ was -6.313 greater than $\mathrm{t}_{\text {table }}$, which was -2.03951 , so $\mathrm{H}_{0}$ was refused, shows there was a remarkable impact between before participating in flipped learning and after participating in flipped learning.

Based on the probability value, for the side test using the 2-sided test, the test criteria by looking at the sig $(\alpha)$ value where:

refused.

$$
\text { If the sig }(\alpha) \text { value }<0.05 \text { then } \mathrm{H}_{0} \text { is }
$$

received

$$
\text { If the } \operatorname{sig}(\alpha) \text { value }>0.05 \text { then } \mathrm{H}_{0} \text { is }
$$

Evaluating from the previous outcome, it is seen that before and after the implementation of FL for 3 cases with a noteworthy value of $0.000<0.05, \mathrm{H} 0$ is refused and $\mathrm{H} 1$ is acknowledged. This implies that there's a critical impact between before taking an interest in FL and after taking an interest in FL

From these two decisions, that can be ceased that FL is suitable in improving the writing skills of students.

Regarding to the above analysis, it can be ceased that FL is an proper pedagogical approach to develop students' writing skills. 0Students show better performance after being taught with FL via Google Classroom. These results coincide with the results of a study conducted by (Hung, 2015; Stone, 2012; Vitanofa \& Anwar, 2017; Yang, Yin, \& Wang, 2018). In addition, this study shows that FL gives students more time to have face-to-face interactions with lecturers while working on assignments both inside and outside class during the online discussion stage. This is because pre-class and post-class activities have helped students to have better preparation. Thus, they have mastered basic knowledge and can identify gaps between their knowledge and the obstacles they face when completing writing assignments. This connected with study proposed by (Stone, 2012) which provides the importance of providing free time in class through the opportunity to watch recorded material at home because this process helps explain difficult concepts and makes connections between the material studied and everyday life. (Bergmann \& Sams, 2012) further underline that some of the other advantages of the FL method include the development of continuous learning, increased involvement in the material being taught, and increased interaction between students and faculty. Other researchers also support this claim by stating that FL teaching methods are learnercentered because they play a very active role, especially activities in the classroom (Baepler, Walker, \& Driessen, 2014; Basal, 2015; Bishop $\&$ Verleger, 2013; Davies et al., 2013), while the role of the lecturer changes the role of guiding, facilitating, and organizing (Basal, 2015; Bishop \& Verleger, 2013).

The findings of this study are no exception to the general trend as previously expressed by (Herreid \& Schiller, 2013) which states that FL gives better possibility for the education of students, develop student grade and make attractive and communicative lesson. The implementation of FL through three phases provide information that FL gives a positive effect on students' writing skill because students compile better essays according to the instructions given by the lecturer. The extra time provided for in-class and outside-class feedback through Google Classroom also benefits students because the positive effect is evident on their 
final grades in the second cycle. So, Google Classroom is not just additional digital material in this learning process.

\section{CONCLUSION}

FL is suggested as an alternative methodology for learning English in colleges, particularly within the setting of instructing beneficial aptitudes. The viability of the FL approach plays an critical role in upgrading selflearning within the ESP with the nonappearance of face-to-face process such as those happened during the COVID-19 pandemic. The three successive stages counting pre-class, in-class and post-class are sessions in FL assisting students accomplish in arranging, objection setting and implementation of lesson by assignments.

Activities in the classroom are monitored by the lecturer and promote deeper learning about concepts and problem solving. Independent learning and elaboration at the pre-class and postclass stages are tightly dealt with attempt to manage and rule aspects of autonomous learning. Therefore, FL helps give students unlimited space and time to deepen their knowledge of the courses being taught. The process of applying this method is quite challenging because students are faced with an adaptation process with a new method that requires them to intensively understand the content outside the classroom. Thus, they can prepare themselves to complete assignments during class hours. This causes the FL method to require clear, concise and wellstructured instructions.

With access to clear guidelines and stages, a complete correlation can be established between activities in and outside the classroom. To gain more insight into the implementation of FL in ESP, it is necessary to carry out further research involving a larger population and more complex variables. In addition, another aspect of researching the potential use of the latest online formative assessment tools in student learning is also an interesting area to study.

\section{REFERENCES}

Al-kathiri, F. (2015). Beyond the Classroom Walls : Edmodo in Saudi Secondary School EFL Instruction, Attitudes and Challenges. English Language Teaching, 8(1), 189-204.

Arroyo, C. G. (2011). On-Line Social Networks : Innovative Ways towards the Boost of Collaborative Language Learning. In International Conference ICT for Language Learning 4th Edition. Spain: F Pixel.
Baepler, P., Walker, J. D., \& Driessen, M. (2014). It's not about Seat Time : Blending, flipping, and efficiency in Active Learning Classrooms. Computers \& Education, 78, 227-236.

Balasubramanian, K., Jaykumar, V., \& Fukey, L. N. (2014). A study on "Student preference towards the use of Edmodo as a learning platform to create responsible learning environment." Procedia - Social and Behavioral Sciences, 144, 416-422.

Basal, A. (2015). The Implementation of A Flipped Classroom in Foreign Language Teaching. Turkish Online Journal of Distance EducationTOJDE, 16(4), 27-37.

Bergmann, J., \& Sams, A. (2012). Flip Your Classroom: Reach Every Student in Every Class Every Day. Washington, DC: ISTE.

Bishop, J. L., \& Verleger, M. A. (2013). The Flipped Classroom: A Survey of the Research. In 120th ASEE Annual Conference \& Exposition. Atlanta.

D, E. M., Ingram, R., \& Liu, J. C. (2015). A review of flipped classroom research, practice, and technologies. International HETL Review (IHR).

Davies, R. S., Dean, D. L., \& Ball, N. (2013). Flipping the Classroom and Instructional Technology Integration in a College-level Information Systems Spreadsheet Course. Education Tech Research Dev, 61, 563-580.

Emaliana, I. (2017). Teacher-centered or Studentcentered Learning Approach to Promote Learning? Jurnal Sosial Humaniora, 10(2), 59-70.

Ferreri, S. P., \& O’ Connor, S. K. (2013). Redesign of a Large Lecture Course Into a Small-Group Learning Course. American Journal of Pharmaceutical Education, 77(1), 1-9.

Guraya, S. (2020). Combating the COVID-19 Outbreak with a Technology-driven E-flipped Classroom Model of Educational Transformation. Journal of Taibah University Medical Sciences, 15(4), 253-254.

Güvenç, G. (2018). The Flipped Classroom Approach in Teaching Writing: An Action Research. International Journal of Social Sciences and Education Research, 4(3), 421-432.

Han, Y. J. (2015). Successfully Flipping teh ESL Classroom for Learner Autonomy1. NYS TESOL JOURNA, 2(1), 98-109.

Harris, B. F., Harris, J., Reed, L., \& Zelihic, M. (2016). Flipped Classroom: Another Tool for Your Pedagogy Tool Box. Developments in Business Simulation and Experiential Learning, 43, 325-333.

Herreid, C. F., \& Schiller, N. A. (2013). Case Studies and the Flipped Classroom. Journal of College Science Teaching, 42(5), 62-66.

Hung, H. (2015). Flipping the classroom for English language learners to foster active learning. 
Computer Assisted Language Learning, 28(1), 81-96.

Khan, M. S. H., \& Abdou, B. O. (2020). Flipped Classroom: How Institutions of Higher Education (HEIs) of Bangladesh Could Move forward during COVID-19 Pandemic. Social Sciences \& Humanities Open, (April), 1-14.

Mclaughlin, J. E., Roth, M. T., Glatt, D. M., Gharkholonarehe, N., Davidson, C. A., Griffin, L. M., ... Mumper, R. J. (2014). The Flipped Classroom: A Course Redesign to Foster Learning and Engagement in a Health Professions School. Academic Medicine, 89(2), 236-243.

Mehring, J. (2016). Present Research on the Flipped Classroom and Potential Tools for the EFL Classroom. Computers in Schools, 33(1), 1-10.

Roehl, A., Reddy, S. L., \& Shannon, G. J. (2013). The Flipped Classroom: An Opportunity to Engage Millennial Students through Active Learning Strategies, 105(2), 44-49.

Sankoff, P. (2014). Taking the Instruction of Law Outside the Lecture Hall: How The Flipped Classroom Can Make Learning More Productive And Enjoyable (For Professors And Students). Alberta Law Review, 51(4), 891906.

Soliman, N. A. (2016). Teaching English for Academic Purposes via the Flipped Learning Approach. Procedia - Social and Behavioral Sciences, 232(April), 122-129.

Stone, B. B. (2012). Flip Your Classroom to Increase Active Learning and Student Engagement, 15.

Sun, J. C.-Y., \& Wu, Y.-T. (2016). Analysis of Learning Achievement and Teacher-Student Interactions in Flipped and Conventional Classrooms. International Review of Research in Open and Distributed Learning, 17(1), 7999.

Susana, K., \& Brahma, A. A. (2020). The
Implementation of Flipped Learning in Writing Class During the Pandemic: Students' Perceiption and Reflection. International Seminar on Language, Education, \& Culture (ISoLEC), 68-75.

Szparagowski, R. (2014). The Effectiveness of the Flipped Classroom. Honor Projects, 127, 131.

Tune, J. D., Sturek, M., \& Basile, D. P. (2013). Flipped classroom model improves graduate student performance in cardiovascular , respiratory, and renal physiology. Advances in Physiology Education, 37, 316-320.

Vitanofa, A., \& Anwar, K. (2017). The Effect of Flipped Learning through Graphic Organizers toward Writing Skill at MAN 2 Gresik. Journal of English Teaching, Literature, and Applied Linguistics, 1(2), 37-49.

Wallace, M., Walker, J., Braseby, A., \& Sweet, M. (2014). . (). "Now, What Happens during Class?" Using Team-Based Learning to Optimize the Role of Expertise within the Flipped Classroom. Journal on Excellence in College Teaching.

White, P. J., Naidu, S., Yuriev, E., Short, J. L., Mclaughlin, J. E., \& Larson, C. (2017). Student Engagement with a Flipped Classroom Teaching Design Affects Pharmacology Examination Performance in a Manner Dependent on Question Type. American Journal of Pharmaceutical Education, 81(9), $10-23$

Wichadee, S. (2017). A Development of the Blended Learning Model Using Edmodo for Maximizing Students' Oral Proficiency and Motivation. IJET, 12(2), 137-154.

Yang, J., Yin, C., \& Wang, W. (2018). Flipping the Classroom in Teaching Chinese as a Foreign Language. Language Learning \& Technology, 22(1), 16-26. 